\title{
Temperature affects respiration rate of Oithona similis
}

\author{
Claudia Castellani ${ }^{1,2,3, *}$, Carol Robinson ${ }^{2}$, Tania Smith ${ }^{2}$, Richard S. Lampitt ${ }^{1}$ \\ ${ }^{1}$ Southampton Oceanography Centre, European Way, Southampton SO14 3ZH, UK \\ ${ }^{2}$ Plymouth Marine Laboratory, Prospect Place, Plymouth PL1 3DH, UK \\ ${ }^{3}$ Present address: British Oceanographic Data Centre (BODC), Proudman Oceanographic Laboratory, 6 Brownlow Street, \\ Liverpool L3 5DA, UK
}

\begin{abstract}
Oithona spp. is considered the most abundant and ubiquitous copepod genus in the marine environment, often outnumbering calanoid copepods throughout the year. Previous studies have argued that one of the reasons for such success is that the respiration rate of Oithona spp. is insensitive to temperature changes and lower than in calanoids. However, comprehensive data on the thermal biology of this important copepod genus is lacking. In this study, the respiration rate of adult female $O$. similis from the English Channel, was measured over the temperature range 4 to $25^{\circ} \mathrm{C}$. The respiration rate of $O$. similis changed exponentially with temperature $\left(\ln \mathrm{O}_{2}\right.$-rate $=-3.59+$ $0.114 T, \mathrm{df}=35, \mathrm{r}^{2}=0.85, \mathrm{p}<0.001, Q_{10}=3.1$ ) similar to that of other poikilotherms. Over the temperature range examined, $O$. similis basic metabolic cost varied from a minimum of $\sim 1.4 \%$ body-C $\mathrm{d}^{-1}$ at $4{ }^{\circ} \mathrm{C}$ to a maximum of $23 \%$ body- $\mathrm{C} \mathrm{d}^{-1}$ at $25^{\circ} \mathrm{C}$, corresponding to an energy demand of $\sim 3 \%$ and $32 \%$ body $-\mathrm{C} \mathrm{d}^{-1}$ respectively. The respiration rate of $O$. similis, from the present study, is $\sim 8$ times lower than that of a calanoid copepod of equivalent body weight estimated from published empirical metabolism-temperature data. We suggest that these differences in metabolic rates may account for the year-round persistence and higher abundances of Oithona spp. over calanoid copepods, particularly in oceanic and oligotrophic environments where food resources may be limiting for calanoid copepods.
\end{abstract}

KEY WORDS: Oithona similis $\cdot$ Respiration rate $\cdot$ Temperature $\cdot$ Cyclopoid $\cdot$ Calanoid $\cdot$ Energy demand Resale or republication not permitted without written consent of the publisher

\section{INTRODUCTION}

Paffenhöfer (1993) has argued that low respiratory rates may be one of the explanations for the high abundance and ubiquity of Oithona spp. (Bigelow 1926, Nishida 1985, Gallienne \& Robins 2001). Nevertheless, there has been no comprehensive study on the respiration rate of this widespread copepod group. Previous investigations have concluded that the respiration rate of Oithona spp. is temperature-insensitive (Marshall \& Orr 1966, Lampitt \& Gamble 1982, Hiromi et al. 1988, Nakamura \& Turner 1997). Temperature, however, is one of the most important factors affecting the respiration rate of poikilotherms (Schmidt-Nielsen 1991) and zooplankton in general (Ikeda 1974, Ikeda \& Motoda 1978, Vidal 1980, Ikeda et al. 2001). On the other hand, the ability to maintain constant metabolic rates (homeostasis) in spite of temperature changes has been reported for a range of invertebrate species, including copepods (Gaudy et al. 2000, Parra et al. 2003), as an adaptation to rapid temperature fluctuations (eurythermy). With the exception of Hiromi et al. (1988), who measured the respiration rate of $O$. davisae over a wide temperature range, other investigators have studied the respiration of Oithona spp. over narrow ranges (Klekowski et al. 1977, Lampitt \& Gamble 1982, Nakamura \& Turner 1997) or at a single temperature (Marshall \& Orr 1966). Thus, the reported lack of metabolic response to temperature changes in Oithona spp. remains to be verified.

Knowledge of an organism's respiration rate at different temperatures is important, as it provides a basic 
indication of its metabolic requirements in different environments. Estimates of Oithona spp. energy demand in recent field studies have relied on the assumption that Oithona spp. metabolism is either constant with temperature (McKinnon \& Klumpp 1998) or similar to that of calanoid copepods (Atkinson 1996, Lonsdale et al. 2000). The problem with such assumptions is that currently there is still no general consensus on whether the respiration rate of Oithona spp. is lower (Lampitt \& Gamble 1982) or similar (Sabatini \& Kiørboe 1994) to that of calanoid copepods.

Among all cyclopoid species, Oithona similis probably experiences the largest latitudinal and seasonal temperature variation because it has the widest distributional range (Nishida 1985, Nielsen \& Sabatini 1996, Atkinson 1998). Thus, the present study focuses on this species to investigate the relationship between respiration rate and temperature and compare it with published metabolism-temperature relationships for calanoid copepods. The questions we asked are: (1) Does the respiration rate of $O$. similis respond to temperature changes as observed for calanoid copepods and poikilotherms in general? (2) Is the weight-specific respiration rate of $O$. similis similar to that of calanoid copepods?

\section{MATERIALS AND METHODS}

Plankton was collected by gentle vertical hauls from $50 \mathrm{~m}$ depth with a $200 \mu \mathrm{m}$ WP-2 net at Stn L4 $\left(50^{\circ} 15^{\prime} \mathrm{N}, 04^{\circ} 13^{\prime} \mathrm{W}\right)$ in the English Channel between July and December 2003, and the catch was returned to the laboratory within $2 \mathrm{~h}$ of collection in thermally insulated containers. Adult Oithona similis females were isolated with a Pasteur pipette under a dissecting microscope, placed in GF/F-filtered seawater and preconditioned overnight in the dark (Nakamura \& Turner $1997)$ to temperatures between 4 and $25^{\circ} \mathrm{C}\left( \pm 0.1^{\circ} \mathrm{C}\right)$. The incubation temperatures of pre-conditioned copepods were within $\pm 10^{\circ} \mathrm{C}$ of the in situ temperatures (i.e. $15^{\circ} \mathrm{C}$ ). On 3 occasions the experiment was undertaken at the in situ temperatures of $10.5,15$ and $18^{\circ} \mathrm{C}$. The respiration rate of $O$. similis females was determined from in vitro changes in dissolved oxygen. Pre-filtered seawater from Stn L4 was cartridge filtered to $0.2 \mu \mathrm{m}$ (Criticap-100 sterile capsule) into a $10 \mathrm{l}$ autoclaved polycarbonate aspirator and siphoned into $60 \mathrm{ml}$ borosilicate glass bottles. We prepared 4 zero time ( $t$-zero), 4 control and 2 to 4 replicate bottles containing between 25 and 200 O. similis at each temperature. High numbers of $O$. similis ( $>70$ to 80 copepods per bottle) were only used at temperatures lower than $7^{\circ} \mathrm{C}$ when respiration rates became too low to be distinguished from the control.
The $t$-zero replicates were fixed at the start of the experiment. The controls and the experimental bottles were incubated for $24 \mathrm{~h}$ in the dark in temperaturecontrolled incubators in static conditions, as preliminary observations indicated that healthy Oithona similis swims throughout the bottle without the need for artificial re-suspension. The respiration rate of potential bacteria was calculated from the difference in dissolved oxygen between the $t$-zero replicates and the incubated control replicates. The respiration rate of $O$. similis was calculated from the difference in dissolved $\mathrm{O}_{2}$ between the mean of the controls and the experimental bottles at the end of the incubation. Measurements of dissolved oxygen were made with an automated Winkler titration system with a photometric endpoint (Williams \& Jenkinson 1982). Chemical reagents were based on Carrit \& Carpenter (1966) and the oxygen saturation was calculated from the equations for the solubility of oxygen in seawater of Benson \& Krause (1984).

The Oithona similis used in the experiments were sized using an ocular micrometer to the nearest $20 \mu \mathrm{m}$ and the copepod's carbon content was derived from the length-weight relationship of Sabatini \& Kiørboe (1994). The weight-specific respiration rate of O. similis was then calculated from the ratio between the respiration rate of the copepods and their estimated body carbon (body-C). The metabolic response of O. similis to temperature was determined as a $Q_{10}$ estimated from the relationship: $Q_{10}=\mathrm{e}^{(10 \times \text { slope })}$, where e is the base of the natural log and the slope is the gradient obtained from the regression analysis between respiration rate and temperature.

The salinity of the seawater used in the incubation was also measured with a portable salinometer (Model WTW LF-197) fitted with a salinity/temperature sensor (TetraCon 325) to enable oxygen saturation to be calculated.

\section{RESULTS}

There was no evidence of density-dependence of respiration over the range of copepod concentrations used, as respiration rates (standardised to $15^{\circ} \mathrm{C}$ using a $Q_{10}$ of 3.1 found in the present study) were not significantly correlated $(\mathrm{r}=-0.25, \mathrm{df}=35, \mathrm{p}=0.160)$ with the number of individuals per bottle (Fig. 1).

The weight-specific respiration rate of Oithona similis increased exponentially with increasing temperature ranging from $0.026 \mu \mathrm{O}_{2} \mu \mathrm{g} \mathrm{C}^{-1} \mathrm{~d}^{-1}$ at $4.6^{\circ} \mathrm{C}$ to $0.423 \mu \mathrm{lO}_{2} \mu \mathrm{g} \mathrm{C}^{-1} \mathrm{~d}^{-1}$ at $25^{\circ} \mathrm{C}$ for body weights ranging from 0.5 to $0.6 \mu \mathrm{gC}$ (Fig. 2). Regression analysis after semi-logarithmic transformation of the data was used to establish the relationship between weight-specific 


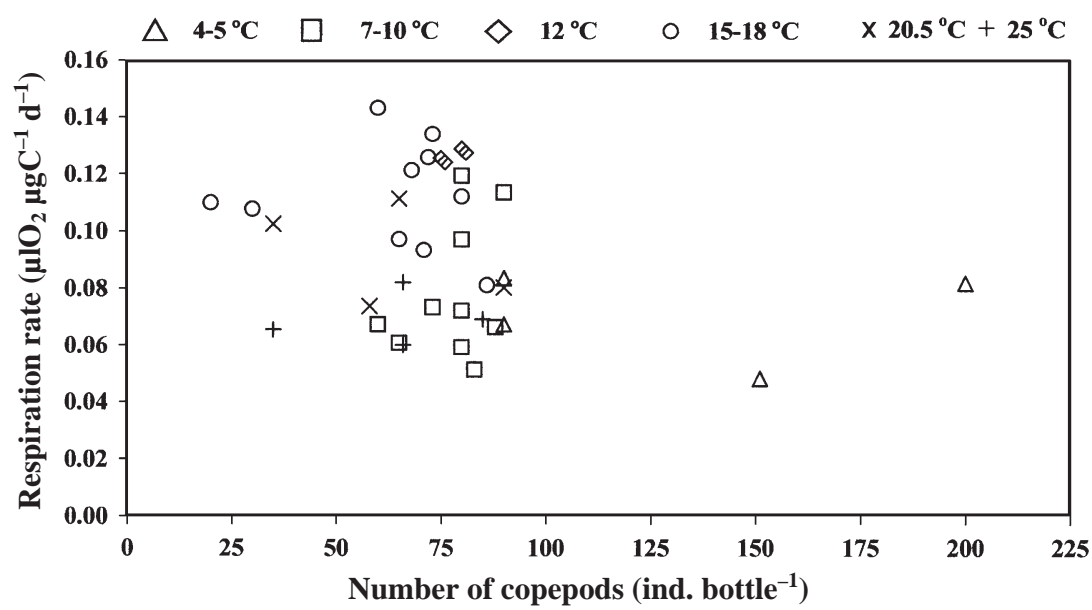

Fig. 1. Oithona similis. Weight-specific respiration rate $\left(\mu \mathrm{O}_{2} \mu \mathrm{gC}^{-1} \mathrm{~d}^{-1}\right)$ versus copepod number per bottle for different temperatures $\left({ }^{\circ} \mathrm{C}\right)$. Rates standardised to $15^{\circ} \mathrm{C}$ using a $Q_{10}$ of 3.1 found in the present study. Please note the pairs of diamond symbols overlapping each other

respiration rate and temperature. The rise in respiration rate of $O$. similis with increasing temperature calculated from the fitted equation corresponded to a $Q_{10}$ of 3.1.

Fig. 2 shows that the respiration rates of Oithona similis acclimated at the field temperature fits the pattern of the metabolism-temperature $(M-T)$ curve for copepods incubated at set laboratory temperatures.

The percentage in oxygen saturation of the seawater at the end of the experiments was between 80 and $100 \%$. Bacterial respiration was low, representing a change of between 0 and $0.5 \%$ of total dissolved oxygen. The standard deviation of the respiration in the control bottles varied from 0.00208 to $0.0066 \mu \mathrm{l} \mathrm{O}_{2}$ copepod $^{-1} \mathrm{~d}^{-1}$.

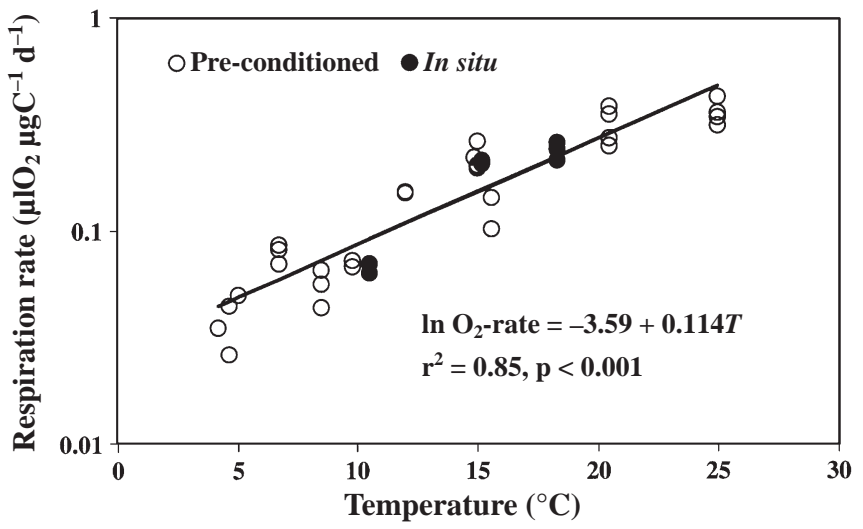

Fig. 2. Oithona similis. Weight-specific respiration rate $\left(\mu \mathrm{O}_{2}\right.$ $\left.\mu \mathrm{g} \mathrm{C}^{-1} \mathrm{~d}^{-1}\right)$ versus temperature $\left(T,{ }^{\circ} \mathrm{C}\right)$ measured at in situ temperature $(\bullet)$ or after pre-conditioning at experimental temperature (०). Note logarithmic scaling

\section{DISCUSSION}

\section{Respiration rates of Oithona spp. and temperature}

The present study measured the respiration rate of Oithona similis over the temperature range 4 to $25^{\circ} \mathrm{C}$ and at in situ acclimation temperatures of $10.5,15$ and $18^{\circ} \mathrm{C}$. To our knowledge this is the first study in which the respiration rate of $O$. similis has been measured over a wide temperature range. Our results show that the respiration rate of $O$. similis varies as a function of temperature $\left(Q_{10}=3.1\right)$, as reported for other poikilotherm organisms including zooplankton (Ikeda \& Motoda 1978, Schmidt-Nielsen 1991, Ikeda et al. 2001).

The overlapping between Oithona similis respiration rates measured at similar temperatures for in situ and pre-conditioned copepods rules out the possibility that the temperature response measured (Fig. 2) was an artifact of laboratory conditions. Similarly, Robinson \& Williams (1993) found that experimental manipulation and temperature acclimation did not bias the respiration rates of plankton community respiration. The present finding contrasts with those of previous studies suggesting that the respiration rate of Oithonidae is temperature-insensitive. Hiromi et al. (1988) could not detect any significant change in the respiration rate of $O$. davisae over the temperature range 5 to $30^{\circ} \mathrm{C}$, whereas, in their seasonal study, Lampitt \& Gamble (1982) could not find any relationship between the respiration rate of $O$. nana and environmental temperatures between 7 and $12^{\circ} \mathrm{C}$ (R. Lampitt pers. comm.). More recently, Nakamura \& Turner (1997), measuring the respiration rate of $O$. similis at 19 and $20.5^{\circ} \mathrm{C}$, found comparable rates to those reported by Marshall \& Orr (1966) for $\mathrm{O}$. similis at $10^{\circ} \mathrm{C}$ and concluded that the effect of temperature on the respiration rate of oithonids may be minimal. However, the respiration rates from 0.14 to $0.21 \mu \mathrm{O}_{2}$ copepods (cop) $)^{-1} \mathrm{~d}^{-1}$ measured in the present study for $O$. similis at $20^{\circ} \mathrm{C}$ in laboratory conditions overlap with the 0.20 to $0.23 \mu \mathrm{O}_{2}$ $\operatorname{cop}^{-1} \mathrm{~d}^{-1}$ reported by Nakamura \& Turner (1997) at 19 and $20.5^{\circ} \mathrm{C}$ for the same species. In addition, observations that $O$. similis could survive for $>10 \mathrm{~d}$ without food led Marshall \& Orr (1966) to conclude that the respiration rates they measured for this cyclopoid species were probably too high.

Copepod body weight and nutritional condition are all factors known to alter the relationship between metabolic rates and temperature (Vidal 1980, Kiørboe 
et al. 1985, Ikeda et al. 2000). In the present study the majority of the respiration rate measurements (i.e. preconditioned Oithona similis) were made over a relatively short time span (i.e. $1 \mathrm{mo}$ ) during which in situ temperature, copepod size and the concentration/composition of potential food sources remained approximately constant (C. Castellani pers. obs.). Thus, it is possible that the lack of correlation between $O$. nana respiration rate and temperature reported by Lampitt \& Gamble (1982) in their seasonal study resulted from measuring copepods of very different body weights and nutritional states over a narrow temperature range (i.e. 7 to $12^{\circ} \mathrm{C}$ ).

Table 1 summarises the respiration rates reported for different Oithona spp. in the literature. The rates measured with the bottle incubation for Oithona similis (i.e. 1.4 to $28 \%$ body-C d ${ }^{-1}$ ) of similar body weight and temperature range (present study and Nakamura \& Turner 1997) are less variable than rates derived from the diver-/micro-respirometer method for Oithona spp. (i.e. 8 to $88 \%$ body-C d $d^{-1}$, Klekowski et al. 1977). In larger Oithona species this variation appears even wider, with metabolic rates ranging between $\sim 6$ and $265 \%$ body-C d ${ }^{-1}$ (Klekowski et al. 1977). In contrast, the maximum \% body-C respired per day by calanoid copepods weighing between $3 \mu \mathrm{gC}$ and $4 \mathrm{mgC}$ measured at between -1 and $29^{\circ} \mathrm{C}$ (Vidal 1980, Kiørboe et al. 1985, Ikeda et al. 2001) and most cyclopoids (Table 1 ) is at most $\sim 31 \%$ body-C d $\mathrm{d}^{-1}$. Comparisons of the similarly sized $O$. nana (Lampitt \& Gamble 1982) and O. davisae (Nakata \& Nakane 1987, Hiromi et al. 1988) also suggest that the respiration measured for this latter species represent maximum rates.

The chances of a copepod encountering the wall of the experimental vessel is higher in the micro-respirometer (1 to $10 \mu \mathrm{l}$ ) than in the bottle $(60 \mathrm{ml})$ and this may result in the copepod being more stressed and having a higher metabolic rate when the former method is used. Although incubation of multiple individuals may also present a drawback of the bottle incubation technique through a crowding effect, in the present study, Oithona similis respiration rate was unrelated to copepod concentration, indicating that the number of individuals incubated did not affect our results (Fig. 1). In addition, higher metabolic rates reported for the microrespirometer might have also arisen from high bacterial growth due to coarsely filtered (i.e. $>0.2 \mu \mathrm{m}$ ) seawater (Hiromi et al. 1988). Thus, it is possible that the method used by Klekowski et al. (1977) and Hiromi et al. (1988) was responsible for the higher and more variable Oithona spp. respiration rates they reported.

\section{Respiration rate of Oithona spp. versus calanoid copepods}

Paffenhöfer (1993) argued that lower metabolic requirements may give an 'edge' to Oithona spp. over

Table 1. Oithona spp. Summary of respiration rates (range) reported in the literature at different locations. T: temperature $\left({ }^{\circ} \mathrm{C}\right)$; WT: copepod carbon weight $(\mu \mathrm{gC})$; cop: copepods; $R$ : respiration rate $\left(\mu \mathrm{lO}_{2} \operatorname{copepod}^{-1} \mathrm{~d}^{-1}\right) ; R_{\mathrm{sp}}$ : weight-specific respiration rate $\left(\mu l \mathrm{O}_{2} \mu g \mathrm{C}^{-1} \mathrm{~d}^{-1}\right)$, Body-C $\mathrm{d}^{-1}$ : body carbon respired daily (\%)

\begin{tabular}{|c|c|c|c|c|c|c|c|c|}
\hline Species & $\begin{array}{c}T \\
\left({ }^{\circ} \mathrm{C}\right)\end{array}$ & $\begin{array}{l}\text { WT } \\
(\mu g C)\end{array}$ & $\begin{array}{c}R \\
\left(\mu \mathrm{lO}_{2} \operatorname{cop}^{-1} \mathrm{~d}^{-1}\right)\end{array}$ & $\begin{array}{c}R_{\mathrm{sp}} \\
\left(\mu \mathrm{IO}_{2} \mu \mathrm{C} \mathrm{C}^{-1} \mathrm{~d}^{-1}\right)\end{array}$ & $\begin{array}{l}\text { Body-C } \\
d^{-1}(\%)\end{array}$ & Method & Location & Source \\
\hline O. similis & $4-25$ & $0.5-0.6^{\mathrm{a}}$ & $0.019-0.25$ & $0.026-0.42$ & $1.4-22.6$ & Winkler & $\begin{array}{l}\text { Stn L4, English } \\
\text { Channel, UK }\end{array}$ & This study \\
\hline O. similis & $19-20.7$ & $0.44^{\mathrm{a}}$ & $0.20-0.23$ & $0.45-0.52$ & $24.4-28$ & Winkler & $\begin{array}{l}\text { Buzzards Bay, } \\
\text { MA, USA }\end{array}$ & $\begin{array}{l}\text { Nakamura \& Turner } \\
(1997)\end{array}$ \\
\hline O. similis & 10 & $0.54-1.13^{b}$ & $0.28-0.36$ & $0.47-0.56$ & $12-31.5$ & Fox-Wingfield & Clyde Sea, UK & Marshall \& Orr (1966) \\
\hline O. nana & $7-12$ & $0.20^{\mathrm{c}}$ & $0.02-0.078$ & $0.1-0.38$ & $5.3-20.8$ & Winkler & $\begin{array}{l}\text { Loch Thurnaig, } \\
\text { Scotland, UK }\end{array}$ & $\begin{array}{l}\text { Lampitt \& Gamble } \\
\text { (1982) }\end{array}$ \\
\hline O. davisae & $5-30$ & $0.23^{c}$ & $0.11-0.14$ & $0.51-0.68$ & $25.6-31.4$ & Diver-respirometer & $\begin{array}{l}\text { Shibaura, Tokyo } \\
\text { Bay, Japan }\end{array}$ & Hiromi et al. (1988) \\
\hline O. davisae & 25 & $0.23^{\mathrm{c}}$ & 0.13 & 0.56 & 30.3 & Diver-respirometer & $\begin{array}{l}\text { Shibaura, Tokyo } \\
\text { Bay, Japan }\end{array}$ & $\begin{array}{l}\text { Nakata \& Nakane } \\
\text { (1987) }\end{array}$ \\
\hline Oithona spp. & $19.4-22.5$ & $0.46-0.6^{\mathrm{b}, \mathrm{c}}$ & $0.13-0.62$ & $0.25-1.22$ & $7.9-88.8$ & Micro-respirometer & $\begin{array}{l}\text { Pacific } \\
\text { Ocean }^{\mathrm{d}}\end{array}$ & Klekowski et al. (1977) \\
\hline O. plumifera & $22.5-25.5$ & $0.3-1.52^{b, c}$ & $0.12-0.79$ & $0.10-1.65$ & $5.5-88$ & Micro-respirometer & $\begin{array}{l}\text { Pacific } \\
\text { Ocean }^{d}\end{array}$ & Klekowski et al. (1977) \\
\hline O. setigera & $22.5-25.5$ & $0.28-1.52^{\mathrm{b}, \mathrm{c}}$ & $0.34-1.02$ & $0.22-3.62$ & $12.1-194$ & Micro-respirometer & $\begin{array}{l}\text { Pacific } \\
\text { Ocean }^{d}\end{array}$ & Klekowski et al. (1977) \\
\hline O. tenuis & $22.5-24.5$ & $0.19-1.37^{\mathrm{b}, \mathrm{c}}$ & $0.31-0.94$ & $0.23-4.95$ & $12.3-265$ & Micro-respirometer & $\begin{array}{l}\text { Pacific } \\
\text { Ocean }^{\mathrm{d}}\end{array}$ & Klekowski et al. (1977) \\
\hline
\end{tabular}


Table 2. One-sample $t$-test between $\ln$-transformed mean respiration rate $\left(R, \mu l \mathrm{O}_{2}\right.$ copepod $\left.^{-1} \mathrm{~d}^{-1}\right)$ standardised to $15^{\circ} \mathrm{C}$ using $Q_{10}$ for Oithona similis (present study) and calanoid copepod of equivalent body mass (i.e. weight $[\mathrm{WT}]=0.56 \mu \mathrm{gC}$ ) estimated from regression line of Ikeda et al. (2001) in Fig. 3. $\mathrm{n}$ : number of observations; $95 \% \mathrm{CI}$ : confidence intervals of means; $R$-ratio: ratio between respiration rate estimated for $O$. similis and a calanoid copepod

\begin{tabular}{|lccccccc|}
\hline Group & $\mathrm{n}$ & $\ln \mathrm{WT}$ & $\ln R$ & $95 \% \mathrm{CI}$ & $t$-value & $\mathrm{p}$-value & $R$-ratio \\
\hline Calanoid & 43 & -0.571 & $\begin{array}{c}-0.3423 \\
( \pm 0.0011)\end{array}$ & $-0.364,-0.321$ & & & \\
& & & -42.88 & $<0.001$ & 8.33 \\
O. similis & 36 & -0.571 & $\begin{array}{c}-2.4619 \\
( \pm 0.0494)\end{array}$ & $-2.562,-2.362$ & & & \\
& & & & & & \\
\end{tabular}

expended not only in swimming speed, but also in the movement of mouth-parts. Thus, the lower metabolic rates of $O$. similis could also be attributable to the absence of a feeding current.

Their smaller size, transparency and reduced motion probably make Oithona spp. less conspicuous than calanoids to both tactile and visual predators (Paffenhöfer 1993, Atkinson \& Snyder 1997). Recently, Eiane \& Ohman (2004) have shown that overall O. similis suffers lower mortality rates

calanoid copepods (e.g. in situations where food sources are low) and could be one of the reasons why Oithona spp. are so ubiquitous and abundant. Although several investigations have noted that the respiration rate of Oithona spp. is lower than that of calanoids (Lampitt \& Gamble 1982, Nakamura \& Turner 1997), this hypothesis has not been thoroughly tested. In addition, other studies have challenged this idea, attributing the success of Oithona spp. more to its ability to feed on a wider size range and diversity of prey (Lampitt 1978, Uchima 1988, Gonzalez \& Smetacek 1994, Roff et al. 1995, Lonsdale et al. 2000) rather than to real differences in the metabolic rates between Oithona spp. and calanoids (Sabatini \& Kiørboe 1994, Nielsen \& Sabatini 1996).

We compared the data of Oithona similis from this study with those of calanoid copepods from Table 2 in Ikeda et al. (2001), since the respiration rates were measured using similar methods (Fig. 3). To make the comparison possible, the 2 sets of data were first standardised to $15^{\circ} \mathrm{C}$ using the $Q_{10}$ found by Ikeda et al. (2001) and by the present study for calanoids and $O$. similis respectively. Fig. 3 shows that the regression line relating respiration rate and body mass of calanoids lies above the data of the cyclopoids. A 1 -sample $t$-test (Table 2) indicated that the mean respiration rate of an $O$. similis female is significantly lower (i.e. 8 times) than that of a calanoid copepod of similar body mass estimated from the regression analysis of Ikeda's (2001) data.

The lower respiration rate of Oithona similis may reflect different physiological, behavioural and ecological adaptations from those of calanoid copepods to life in the pelagial. Oithona spp. are ambush and coprophagus feeders, mostly drifting passively without generating a feeding current (Svensen \& Kiørboe 2000, Paffenhöfer \& Mazzocchi 2002). Thus, whereas calanoids spend on average $80 \%$ of their time swimming, Oithona spp. copepodites only move $0.9 \%$ or less of the time (Paffenhöfer 1993, Hwang \& Turner 1995, Paffenhöfer \& Mazzocchi 2002). However, energy is than Calanus finmarchicus and Pseudocalanus elongatus. Thus, the high abundance often reported for Oithona spp. (Gallienne \& Robins 2001 and references therein) could be equally accounted for by both lower metabolic and mortality rates, as these are directly related to reduced swimming activity.

The relationship between respiration and temperature (Fig. 2) allows calculation of the basic metabolic costs and energetic requirements that must be met by an adult female Oithona similis to survive over a wide temperature range. Such information is very important, particularly for an organism such as $O$. similis, whose distribution extends from polar to tropical oceans. Thus, our study predicts that the cost of respiration for $O$. similis varies from a minimum of $\sim 1.4 \%$ body-C d $\mathrm{d}^{-1}$ at $4^{\circ} \mathrm{C}$ to a maximum of $23 \%$ body- $\mathrm{C} \mathrm{d}^{-1}$ at $25^{\circ} \mathrm{C}$, corresponding to an energy demand of $\sim 3 \%$ and $32 \%$ body- $\mathrm{C} \mathrm{d}^{-1}$ (i.e. assuming a respiratory quotient, $R Q$, of 0.8 [for protein metabolism] and assimilation efficiency, $A$, of 0.7 [Ikeda \& Motoda 1978]) respectively.

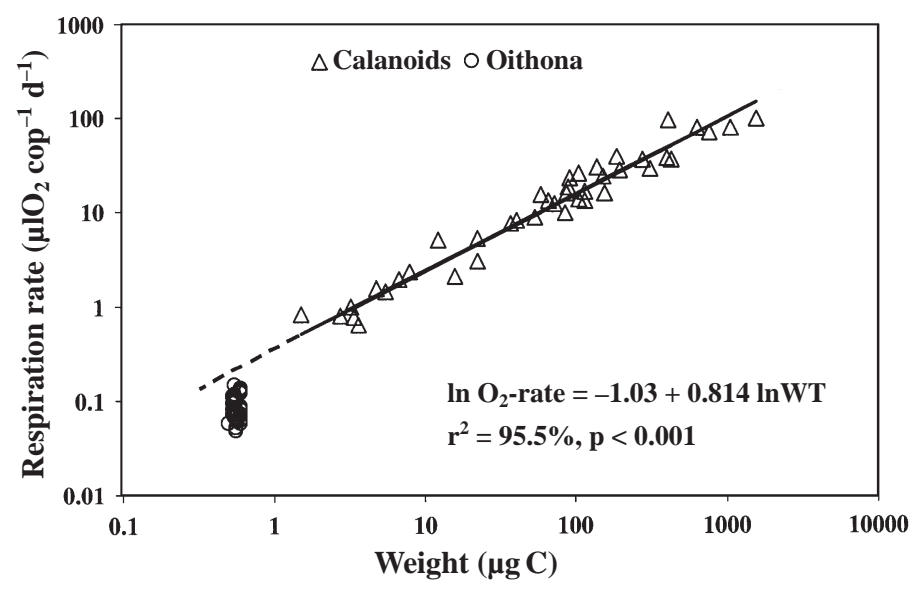

Fig. 3. Respiration rate $\left(\mu \mathrm{O}_{2}\right.$ copepod $\left.^{-1} \mathrm{~d}^{-1}\right)$ of Oithona similis (present study) and of calanoid copepods (Ikeda et al. 2001) versus body mass (WT in $\mu \mathrm{gC}$ ). All values standardised to $15^{\circ} \mathrm{C}$ using appropriate $Q_{10}$ 
Reported in situ ingested carbon for Oithona similis of 5 to $327 \%$ body-C d $\mathrm{d}^{-1}$ at temperatures between -1 and $6.5^{\circ} \mathrm{C}$ in the sub-antarctic respectively (Atkinson \& Shreeve 1995, Atkinson 1996, Swadling et al. 1997, Lonsdale et al. 2000) and up to $40 \%$ in temperate areas (Lampitt \& Gamble 1982, Nakamura \& Turner 1997) are in excess of the energy demand for respiration estimated by the present study. In addition, the coprophagus feeding of $O$. similis spp. (Gonzalez \& Smetacek 1994) signifies that published feeding rates probably represent underestimates, as ingestion of faecal pellets in feeding experiments is rarely taken into account. These observations suggest that Oithona spp. is less dependent on microplankton blooms and thus less likely to suffer mortality rates due to starvation than calanoids.

The success of Oithona spp. is probably dependent on more than one factor. We argue, however, that lower metabolic needs may increase the chances of survival and reproduction of $O$. similis and contribute to explaining its higher abundance in oceanic oligotrophic environments, and in winter, when food resources may become limiting for the majority of calanoid copepods.

Acknowledgements. We wish to thank X. Irigoien, R. P. Harris, A. G. Hirst, Thomas Kiørboe and 3 anonymous referees for improving the paper with their comments. This study was funded by the Natural Environment Research Council thematic programme Marine Productivity (grant NER/T/S/ 2001/00140) and the Plymouth Marine Laboratory Core Strategic Research Programme.

\section{LITERATURE CITED}

Atkinson A (1996) Subantarctic copepods in an oceanic, low chlorophyll environment: ciliate predation, food selectivity and impact on prey populations. Mar Ecol Prog Ser 130: 85-96

Atkinson A (1998) Life cycle strategies of epipelagic copepods in the Southern Ocean. J Mar Syst 15:289-311

Atkinson A, Shreeve RS (1995) Response of copepod community to a spring bloom in the Bellingshausen Sea. Deep-Sea Res 42:1291-1311

Atkinson A, Snyder R (1997) Krill-copepod interaction at South Georgia, Antarctica, I. Omnivory by Euphasia superba. Mar Ecol Prog Ser 160:63-76

Bigelow HB (1926) Plankton of the offshore waters of the Gulf of Maine. Bull Bur Fish Wash 40:1-507

Benson BB, Krause D Jr (1984) The concentration and isotopic fractionation of oxygen dissolved in freshwater and seawater in equilibrium with the atmosphere. Limnol Oceanogr 29:620-632

Carrit DE, Carpenter JH (1966) Comparison and evaluation of currently employed modifications of the Winkler method for determining dissolved oxygen in seawater; a Nasco report. J Mar Res 24:86-319

Eiane K, Ohman MD (2004) Stage-specific mortality of Calanus finmarchicus, Pseudocalanus elongatus and Oithona similis on Fladen Ground, North Sea, during a spring bloom. Mar Ecol Prog Ser 268:183-193
Gallienne CP, Robins DB (2001) Is Oithona the most important copepod in the world's oceans? J Plankton Res 12: 1421-1432

Gaudy R, Cervetto G, Pagano M (2000) Comparison of the metabolism of Acartia clausi and A. tonsa: influence of temperature and salinity. J Exp Mar Biol Ecol 247:51-65

Gonzalez HE, Smetacek V (1994) The possible role of the cyclopoid copepod Oithona in retarding vertical flux of zooplankton faecal material. Mar Ecol Prog Ser 113: 233-246

Hiromi J, Nagata T, Katoda S (1988) Respiration of the small planktonic copepod Oithona davisae at different temperatures. Bull Plank Soc Jpn 35:143-148

Hwang JS, Turner JT (1995) Behaviour of cyclopoids, harpacticoid and calanoid copepods from coastal waters of Taiwan. PSZN I: Mar Ecol 16:207-216

Ikeda T (1974) Nutritional ecology of marine zooplankton. Mem Fac Fish Hokkaido Univ 22:1-97

Ikeda T, Motoda S (1978) Estimated zooplankton production and their ammonia excretion in the Kuroshio and adjacent seas. Fish Bull (Wash DC) 76:357-367

Ikeda T, Torres JJ, Hernandez-Leon S, Geiger SP (2000) Metabolism. In: Harris RP, Wiebe PH, Lenz J, Skioldal HR, Huntley M (eds) ICES zooplankton methodology manual. Academic Press, London

Ikeda T, Kanno Y, Ozaki K, Shinada A (2001) Metabolic rates of pelagic marine copepods as a function of body mass and temperature. Mar Biol 139:587-596

Kiørboe T, Mohlenberg F, Hamburger K (1985) Bioenergetics of the planktonic copepod Acartia tonsa: relation between feeding, egg production and respiration and composition of specific dynamic action. Mar Ecol Prog Ser 26:85-97

Klekowski RZ, Kukina IV, Tumanseva NI (1977) Respiration in the microzooplankton of the equatorial upwellings in the eastern Pacific Ocean. Pol Arch Hydrobiol (Suppl) 24: $467-489$

Lampitt RS (1978) Carnivorous feeding by a small marine copepod. Limnol Oceanogr 23:1228-1230

Lampitt RS, Gamble JC (1982) diet and respiration of the small planktonic marine copepod Oithona nana. Mar Biol 66:185-190

Lonsdale DJ, Caron DA, Dennet MR, Schaffner R (2000) Predation by Oithona spp. on protozooplankton in the Ross Sea, Antarctica. Deep-Sea Res II 47:3273-3283

Marshall SM, Orr AP (1966) Respiration and feeding in some small copepods. J Mar Biol Assoc UK 46:513-530

Mauchline J (1998) The biology of calanoid copepods. Adv Mar Biol 33:1-710

McKinnon AD, Klumpp DW (1998) Mangrove zooplankton of the North Queensland, Australia. Hydrobiologia 362: $145-160$

Nakamura Y, Turner JT (1997) Predation and respiration by the small cyclopoid copepod Oithona similis: How important is feeding on ciliates and heterotrophic flagellates? J Plankton Res 19:1275-1288

Nakata K, Nakane T (1987) Respiration of plankton in the Mikawa Bay. Pollut Control 22:281-294

Nielsen TG, Sabatini M (1996) Role of cyclopoid copepods Oithona spp. in North Sea plankton communities. Mar Ecol Prog Ser 139:79-93

Nishida S (1985) Taxonomy and distribution of the family Oithonidae (Copepoda, Cyclopoida) in the Pacific and Indian Oceans. Bull Ocean Res Inst Univ Tokyo 20:1-167

Paffenhöfer GA (1993) On the ecology of marine cyclopoid copepods (Crustacea, Copepoda). J Plankton Res 15: $37-55$

Paffenhöfer GA, Mazzocchi MG (2002) On some aspects 
of the behaviour of Oithona plumifera (Copepoda: Cyclopoida). J Plankton Res 24:129-135

Parra G, Jimenez-Melero R, Guerrero F (2003) A study of the oxygen consumption rates in the copepod Neolovenula alluaudi (Calanoida). Crustaceana 76:851-858

Robinson C, Williams PJ LeB (1993) Temperature and Antarctic plankton community respiration. J Plankton Res 15: 1035-1051

Roff JC, Turner JT, Webber MK, Hopcroft RR (1995) Bacterivory by tropical nauplii: extent and possible significance. Aquat Microb Ecol 9:165-175

Sabatini M, Kiørboe T (1994) Egg production, growth and development of the cyclopoid copepod Oithona similis. J Plankton Res 16:1329-1351

Schmidt-Nielsen K (1991) Animal physiology, adaptation and environment, 4th edn. Cambridge University Press, Cambridge

Editorial responsibility: Thomas Kiørboe (Contributing

Editor), Charlottenlund, Denmark
Svensen C, Kiørboe T (2000) Remote prey detection in Oithona similis: hydromechanical versus chemical cues. J Plankton Res 22:1155-1166

Swadling KM, Gibson JAE, Ritz DA, Nichols PD, Hughes DE (1997) Grazing of phytoplankton by copepods in eastern Antarctic coastal waters. Mar Biol 128:39-48

Uchima M (1988) Gut content analysis of neritic copepods Acartia omorii and Oithona davisae by a new method. Mar Ecol Prog Ser 48:93-97

Vidal J (1980) Physioecology of zooplankton. III. Effects of phytoplankton concentration, temperature and body size on the metabolic rate of Calanus pacificus. Mar Biol 56: 195-202

Williams PJ LeB, Jenkinson NW (1982) A transportable microprocessor controlled precise Winkler titration suitable for field Station and shipboard use. Limnol Oceanogr 27: 576-584

Submitted: January 3, 2004; Accepted: July 7, 2004 Proofs received from author(s): January 7, 2005 